Karadeniz Uluslararası Bilimsel Dergi

Volume: 42, Summer-2019, p. 254-274

ISSN: 1308-6200 DOI Number: 10.17498/kdeniz.534859

Research Article

Received: March 3, 2019 Accepted: May 6, 2019

This article was checked by iThenticate

\title{
BEKSULTAN NURJEKEULI’NIN “EY, DÜNYA EY!” ADLI ROMANINDA KAZAK KİMLİĞí VE RUS İMAJI
}

\author{
KAZAKH IDENTITY AND RUSSIAN IMAGE IN BEKSULTAN \\ NURJEKEULI'S NOVEL “EY, DÜNYA EY!”
}

\section{КАЗАХСКАЯ ИДЕНТИЧНОСТЬ И РУССКИЙ ОБРАЗ В РОМАНЕ БЕКСУЛТАНА НУРЖЕКЕУЛЫ «ӘЙ, ДУНИЙЕ-АЙ!»}

\section{Yılmaz BACAKLI*}

\section{ÖZ}

Bireyler ve toplumlar için en temel ihtiyaçlardan biri 'tanıma'dır. Tanıma bireyin ya da toplumun 'kendi' varlığına dönük sorgulamalar yoluyla gerçekleşirse ortaya çıkan verilerden elde edilen sonuçlar bireysel veya kolektif kimliği oluşturur. Bu kimliklerden özellikle kolektif kimlik daha çok temelinde etnik ve milli bağların bulunduğu bir kültür zemininde toplumun aidiyet arayışının neticesinde oluşturulmakta ve diğer kolektif kimliklerden bir ayrışmayı da içermektedir. $\mathrm{Bu}$ anlamda toplumun 'kendi' dışında kalan ‘öteki’ kolektif kimliklere bakışı da 'imaj’ı oluşturmaktadır.

Kimlik oluşum süreci, toplumlar için uzun bir zamanda gerçekleşmektedir. Kimliğgin ortaya konmasında toplumlar objektif esaslardan hareket etme çabasındadır. Buna karşılık tanımı yapan yine toplumun kendisi olduğu için 'kimlik' belirli ölçüde sübjektif bir özellik gösterir. İmaj ise karşı toplum konusundaki önyarg1, stereotip ve klişelerden hareketle oluşturulur. Yazılı metinler içerisinde özellikle romanlar; kolektif kimlik ve imaj üretmek, yaymak için en ideal araçlardır. Yazar anlatı türündeki metinlerde; kahramanlar, olaylar üzerinden eserin ait olduğu ve en çok ilişki kurduğu toplumla ilgili oldukça zengin kimlik ve imaj unsurları paylaşır.

Modern Kazak edebiyatının usta yazarlarından Beksultan Nurjekeulı'nın 2016 yılında tarihi vesikalardan da faydalanarak yazdığ 1 'Ey, Dünya Ey!' isimli romanı Kazak Türklerinin 20. asrın hemen başından sonuna kadar yaşadığı yetmiş beş yıllık sürede özellikle Ruslar'la nasıl mücadele ettiğini anlatmaktadır. Bu çalışmada, anılan eserde bir kolektif kimlik biçimi olarak 'Kazak kimliği'nin nasıl ele alındığı, bu kimliğin biçimlenmesine ciddi ölçüde etki eden 'Rus imajı'nın esere nasıl yansıdığı açıklanmaya çalışılacaktır.

Anahtar Kelimeler: Kazak edebiyatı, Kazak kimliği, Rus imajı, Beksultan Nurjekeulı, roman.

* ORCID: 0000-0001-6128-5482 Öğr. Gör. Karabük Üniversitesi, Türk Dili Bölümü, yilmazbacakli@gmail.com 


\section{ABSTRACT}

Identification is the main necessity for both individuals and societies. If identification comes true by the way of individual's or society's examining themselves, the results acquired by emergent datas create invidual or collective identity. Among these identities, especially collective identity is formed on a cultural ground which essentially has ethnic and national bonds. This identity is formed as a result of society's seeking of belonging and includes disintegration from other collective identities. In this sense, society's view of 'other' collective identities except for their own forms 'image'.

Process of identity formation takes a long time for societies. Societies effort to act through objective essences in revealing identity. On the contrary, identity noticeably has subjective property as the society itself makes the definition. 'Image' is formed by looking prejudice, stereotype and cliches about opposite society. Written texts and especially novels are ideal means for producing and spreading collective identity and image. In narrative texts, auther shares rich identity and image elements by means of characters and events, related to society which the work belongs to and has many contacts with.

In his novel named 'Ey, Dünya Ey!' Beksultan Nurjekeul1, one of the master authors of modern Kazakh literatüre, narrates how Kazakh Turks struggled with Russians from the beginning to the end of 20th century, within 75 years time. He wrote this novel in 2016 by utilising historical documents. In this study, as a collective identity form, how Kazakh identity is enbraced and how Russian image, which heavily effects the formation of this identity, reflects on this work is going to be explained. novel

Keywords: Kazakh literatüre, Kazakh identity, Russian image, Beksultan Nurjekeul,,

\section{АННОТАЦИЯ}

Одной из самых основных потребностей личности и общества является «признание». Если признание происходит посредством запросов, направленных против существования самой личности или общества, то полученные результаты, представляются как индивидуальная или коллективная идентичность. Такого рода идентичность, в частности коллективная, формируется на основе культуры этнической принадлежности, национальных связей и поиска принадлежности к обществу, и отличаются от других коллективных общностей. В этом смысле взгляд общества на «другую» коллективную общность вне «себя» формирует «образ».

Процесс формирования идентичности общества происходит в течение длительного периода времени. При определении идентичности общества необходимо следовать объективным принципам. С другой стороны, поскольку признание осуществляет само общество, идентичность имеет некоторую субъективную особенность. Образ, в свою очередь формируется на предубеждениях, стереотипах и различных клише. Письменные тексты и особенно романы являются идеальными инструментами для создания и распространения коллективной идентичности и имиджа. Писатель в излогаемом тексте, описывает довольно богатые элементы общности и имиджа, имеющие отношение к героями и событиями описанным в произведении.

Вышедший в свет в 2016 году роман «Әй, дүнийе-ай!», одного из главных авторов современной казахской литературы Бексултана Нуржекеулы, написан опираясь на исторические документы содержащие сведения о противоборстве 
казахского народа с политической системой в течение 75 лет начиная с начала 20-го века. В данной статье предпринята попытка раскрыть отображение в рассматриваемом произведении «казахской идентичности» как формы коллективной общности, и рассмотреть влияние «русского образа» на ее формирование.

Ключевые слова: казахская литература, казахская идентичность, русский образ, Бексултан Нуржекеулы, роман.

\section{Giriş}

Başlarda karşılaştırmalı edebiyat alanında bir alt disiplin olarak dikkati çeken imgebilim/imajbilim, süreç içerisinde yapılan çalışmalarla bağımsız bir bilim dalı olarak gelişir. Topluluk ya da birey tarafından hem nesnel ve fikri açıdan hem de öznel ve hissi bakımdan yapılan tasvirin adı olarak da tanımlanan imaj/imge, edebî eserlerde çok katlı bir anlatımla karşımıza çıkar (Engin, 2012; 58).

Bir toplumun ya da kültürün iki farklı yüzü olan 'kimlik' ve 'imaj' genellikle aynı kavramlar gibi algılanmaktadır. 'Kimlik' 'kendi'ni keşfetme çabasının sonunda ortaya çıkan ve kim olduğunu bilmek isteyen toplumun, gözlemlenebilen ve nesnel verilerle ortaya koymaya çalıştığı toplumsal karakteridir (Kınacı, 2011; 1665). Toplumun kendisinin sahiplendiği ülke, mitler, tarihi bellek, ekonomi, yasal hak ve görevlerde ortaklığın yanı sıra kitlesel bir kamu kültürünün temellendirdiği kimlik; bireyin kendisinden daha büyük ve nizamî başka bir şeye ait olma ihtiyacından doğmaktadır (Smith, 1994; 31-32). Bireyi aşan ve birçok bireyden müteşekkil ortaklıklar oluşturan bu temel kimlik boyutu kolektif kimlikler olarak nitelendirilebilir. Kolektif kimlikler daha çok etnik kökene ve millet esasına dayanan kapsayıcı kimliklerdir (Açık, 2014 ;149).

Kimliğin biçimlenmesinde etkili olan kavramlardan biri de 'öteki’dir. Zira toplumsal şahsiyet, benzersiz ve özgün olma iddiasını kendisi içerisinde tanımladığı ve aidiyet bağı kurduğu toplumsal yapının tanınan özelliklerinden başka özelliklere sahip bir 'öteki' üzerine kurar (Yıldız, 2007; 10). Bu anlamda 'kimlik' kavramı zorunlu olarak 'kendi' ve 'öteki' kavramlarını da içeren bir mahiyet gösterir.

Toplumun ya da kültürün diğer yüzü olan 'imaj' ise sahiplenilen, ortaya konulan 'kimlik' görünüşünün 'öteki' tarafından algılanma biçimidir. 'İmaj'; daha çok önyargılar, klişe ve stereotipler yoluyla toplumsal karakterlere yüklenen muhayyel niteliklere dayanır. $\mathrm{Bu}$ sebeple test edilemeyen, öznel bir özellik gösterir. Bir bakıma 'kendi' yani 'kimlik' kavramının da tanımı için merkez bir kavram haline gelen ve anlam genişlemesine uğrayan 'imaj' bir milletin diğer bir millet hakkındaki düşünce ve görüşleri olarak anlaşılmaktadır (Talun İnce, 2008; 111).

Kimlik ve imaj kavramlarının oluşup genel bir kabul görmesi uzun bir süreç ve en geniş anlamda bir uzlaşma zemini gerektirir (Kınac1, 2016; 10). Edebiyat ve edebî eser bu anlamda hem sürece hem de uzlaşma zeminine ciddi anlamda katkılar sunar. Daha çok politik durumların şekillendirdiği imajlar edebi eserler marifetiyle yayılır ve kalıcı hale gelir. Çünkü en uzun ömürlü ve etkili 'imaj' türetme aracı yazılı kaynaklar, özellikle romanlardır (Engin, 2012; 60).

\section{Beksultan Nurjekeulı ve Bir İmaj Üretme Aracı Olarak“Ey, Dünya Ey!” Romanı}

Beksultan Nurjekeulı, 1941 yılında Taldıkorğan şehrinin Oktyabır bölgesinde (günümüzde Almatı'nın Jarkent bölgesi) doğar. 1958 yılında Köktal'da lise eğitimini 
tamamladıktan sonra iki yıl aynı yerde bir koyun çiftliğinde işçi olarak çalışır. 1965 yılında S. Kirov Kazak Devlet Üniversitesi Filoloji Fakültesini bitirir. 1965-1968 yılları arasında öğretmenlik yapan yazar, 1976-1992 yılları arasında ise 'Jalın', 'Juldız' ve 'Parasat' dergilerinde yöneticilik ve editörlük yapar. Birçok ödül alan ve Kazakistan Cumhuriyetinin kurulmasında da emeği geçen Nurjekeulı, Kazakistan Yazarlar Birliği üyesidir (Nurjekeulı, 2018; 2).

Nurjekeul1, neredeyse tüm eserlerinde özellikle ‘aşk' konusu üzerinde durur. Ona göre 'aşk' insanı türlü sınamalardan geçirerek olgunlaştıran insana has en önemli duygudur. Kadınları ve aşkı anlatma konusundaki başarısı sebebiyle 'duyguların ressamı', 'kadın sırrının bilgesi' olarak tanınan yazar, eserlerini otobiyografisini de içeren oldukça gerçekçi gözlemlere dayalı bir üslûpla kaleme alır (Kınac1, 2016b; 239-240).

Beksultan Nurjekeulı, hikâye ve romanlarında kadın kahramanların anlatımı ve bakış açısıyla kadınlara has konuları işler. Savaş, gelenek ve hayatın diğer bütün sıkıntılı zamanlarında imkanları ölçüsünde ayakta kalmaya çalışan kadının durumunun ele alındığı eserlerde yapmaya zorlandığı hatalar sebebiyle onun suçlanamayacağı tezi işlenir. 1968 yılında yayınlanan ve bir kadın kahraman tarafından anlatılan "Kinali Maxabbat / Suçlu Aşk" adlı romanda 1940'lı yıllardaki savaş ortamında dul kalan genç bir kadının başından geçen karmaşık olaylar ele alınmaktadır. O yılların sıkıntılı ortamını kahramanların iç dünyasını da başarılı bir şekilde aktararak gerçekçi bir biçimde yansıtan yazar, her biri başka bir erkekten üç çocuğu olan Zeren'i şartların kurbanı olduğu için savunur (Özdemir, 2014; 121).

Yazarın 'Küy Tolğak (1972), 'Kütümen Ötken Ğumır' (Beklemede Geçen Bir Ömür 1974), 'Bir Ğana Mahabbat’ (Bir Tek Sevgi -1982), 'Ayel Jolı Jinişke' (Kadın Yolu İncedir 1998) isimlerinde dört hikâyesi; 'Kinali Maxabbat' (Suçlu Aşk - 1968), 'Erli Zayıptılar' (Karı Koca - 1987), 'Jav Jağadan Alğanda' (Düşman Yaka Paça Olunca - 1993), 'Bir Ökiniş Bir Ümit’ (Bir Pişmanlık Bir Ümit - 2000), ‘Ey, Dünye-ey’ (Oy, Dünya Oy! - 2016) isimlerinde beş roman1; 'Özender Örnektelgen Ölke’ (Nehirlerin Haritasını Çizdiği Ülke - 1984), 'Oy Uşkın’ (Düşünce Kıvılcımı - 2003) isimlerinde iki denemesi vardır.

Nurjekeulı'nın çalışmaya konu olan romanı, 2016 yılında 'Әй, дүние-ай' adıyla yayınlanır. Eser, 2016 yılında edebiyat ve sanat alanında Kazakistan Devlet Ödülüne layık görülür. 2018 y1lında Gulshat Shaikenova tarafından Türkiye Türkçesine 'Ey, Dünya Ey!' adıyla aktarılır. Bu çalışmada eserin Türkiye Türkçesine aktarılan şekli kullanılacaktır. 'Ey, Dünya Ey!', Kazak halkının 1916 yılı olayları ile 1991 yılında bağımsız Kazakistan Cumhuriyetinin kuruluşu arasında geçen 75 yıllık sıkıntılı hayatını ele alır (Nurjekeulı, 2018; 13). Romanda yer verilen olaylar yaşayan tanıkların sözlü ve yazılı kayıtlarının yanı sıra arşiv belgelerinin de desteklediği gerçek hikayelerden hareketle kurgulanır. Roman, 1916-1917 yıllarında Çarlık Rusya'sının bir soykırıma yol açan sömürgeci yaklaşımının trajik sonuçları ile Kazak halkının sınır komşusu ülkelere kaçışını anlatarak başlar. Romanda anlatılan olayların önemi ile ilgili olarak bizzat eserin yazarı Nurjekeulı, yayınlanan mülakatlarının birinde arşiv belgelerine dayanarak 6 milyonluk Kazak halkından yaklaşık 4 milyon kişinin bu dönemde öldüğü bilgisini paylaşır (Dilek-Ahmetova, 2017; 77).

'Ey, Dünya Ey!' romanı, yazarın diğer pek çok eserinde olduğu gibi bir kadın kahramanın bakış açısıyla kaleme alınan, arka planında 'aşk' duygusunun yer aldığı tarihî bir romandır. Tarih ve roman arasında 'zaman' unsuruna bağlı güçlü bir müştereklik vardır. Buna karşılık bir bilim dalı olması nedeniyle sıkı kurallarla sınırlanan tarihe göre, sanatın imkânlarını kullandığı için roman daha rahattır. Geçmiş, şimdi ve gelecek arasında ileriye ya da geriye doğru hareket eden roman yazarı, zamanı esnetip amacı bakımından kullanışlı hale getirir (Yalçın, 2012; 264). 
Eserin tarihî bir roman olması Kazak yazarın aidiyetle bağlı bulunduğu halkı için olaylar ve sanal da olsa kahramanlar üzerinden şekillendirdiği 'kimlik' inşasını daha da anlamlı bir hâle getirmektedir. Yine romanda ele alınan tarihî dönemin ana aktörlerinden biri olan Ruslarla ilgili 'imaj' da yazar tarafından yorumlanan tarihî olayların etkisinde biçimlenmektedir. Eserin bu özelliği her iki kavramın okur tarafından yazarın istediği biçimde anlaşılmasını ve kabullenilmesini kolaylaştırmaktadır.

Eser üç bölümden oluşmaktadır. 'Geçmiş' başlığ ile verilen ilk bölümde 1916 yılının başlarından sonuna kadar geçen bir zaman dilimi yani yaklaşık bir yıllık bir süre anlatılmaktadır. Bu bölümde Çar hükümetinin Kazakları zorla askere alma sürecine karşılık onların isyanı, bu isyan neticesinde yaşanan soykırım ve Çin'e kaçış, Çar'ın ısrarından vazgeçip geçici hükümeti kurması sebebiyle tekrar ülkeye dönüş işlenir. 'Sonra' başlığı ile verilen ikinci bölüm 1917 yılı Ekim Devrimi’nin hemen öncesiyle başlar ve 1924 yılında merkez kahramanlardan Tazabek' in bir Rus tarafindan öldürülüşüne kadar sürer. İlk iki bölüm toplamda sekiz yıllık bir zamanı hikâye etmektedir. İkinci bölümle aynı başlığın kullanıldığı üçüncü bölüm, ikinci bölümün bittiği 1924 yılından 61 sene sonrasına yani 1985'e sıçrar. Ara kısımlar geriye dönüş tekniği ile ve özetlenerek verilir. Romanın bu son bölümü 1991 yılının Aralık ayında Kazakistan’ın bağımsızlığının ilan edildiği gün Şeyi’nin ölümüyle biter.

\section{Rus İmajı \\ 2. Beksultan Nurjekeulı’nın ‘Ey, Dünya Ey!’ Adlı Romanında Kazak Kimliği ve}

Beksultan Nurjekeulı 'Ey, Dünya Ey!' adlı eserinde 'Kazak Kimliği' soy, ırk temelli bir kimlik olarak değil; en temel insanî ilkeleri de içeren kültür temelli bir kimlik olarak ele alınmaktadır. Bu sebeple 'Kazak kimliği'ni oluşturan kültür dairesinin içerisinde gönüllü olarak yaşayan ya da ona tahammül göstermenin ötesinde gıpta ve anlayışla bakan Rus, Kırgız veya başka soydan biri de bu kimlik başlığında değerlendirilmektedir. Bu anlamda 'kendi' olarak adlandırılabilecek 'Kazak kimliği'nin sınırları oldukça esnek olarak verilir.

'Kazak kimliği'nin karşısında 'öteki' olarak konumlanan 'Rus imajı' ise bu kimlik dairesini var eden kültür kodlarına ve en temel insanî ilkelere yabancı olmayı ya da ondan derin bir kopuşu ifade etmektedir. Bu anlamda 'Rus imajı'nı da Ruslarla sınırlamamak gerekmektedir. Ruslardan başka Kalmuklar, Çinliler hatta kendi kültürlerinden koparak ötekileşen Kazaklar bile bu imaj algısı ile anlatılmaktadır.

\section{Kazak Kimliği}

Kazak kültür dairesini biçimlendiren en temel unsur dildir. Eserin kahramanları birbirlerine seslenirken kimliklerini ifade edecek şekilde kültürlerine bağlı ve saygılıdırlar. Roman kahramanının yengesi Jüzük, eşinin kız kardeşine (görümcesine) seslenirken onun asıl ismi olan 'Şeyi' yerine geleneklerine bağlı olarak kendi taktığı 'Jibekcan' ismiyle seslenir. Yine kendilerinden büyük kişilere saygı gereği ismini kısaltıp sonuna saygı gereği '-ke' ekleyerek seslenirler: “...babası bugün tamamen başka birisiydi. İki kelimenin birinde 'Ömeke, Ömeke' diye Tazabek'in babasının önünde kendini küçük göstermişti. Tazabek babasına çekmiştir, ihtiyar Ömerali bağdaş kurarak oturduğunda da büyük görünürdü." (Nurjekeul1, 2018; 37)

Romanın başkahramanlarından Tazabek, yaşadığı yerde öğretmenlik yapma ve Ruslara da dil öğretme konusunda kendisine gelen teklifi reddeder. Ona göre kendi dilini öğrenmesi daha önemlidir. Fakat iyi eğitim almış bir Kazak olan Zarip onu ikna eder: "Eee, Tazabek, Ruslara Kazakça yazmayı ögretmek de bir gurur vesilesi değil mi? Neden kaçıyorsun? Kabul et!'” (Nurjekeul1, 2018; 257) 
Esasen daha romanın başında romandaki olumlu Rus imajını temsil eden ve Kazak kimliğinin kültür dairesi içerisine de alınan Sofya ile romanın ilerleyen bölümlerinde olaylara dâhil olan Kobzev'in iyi derecede Kazakça bilmesi de dilin kimlik inşasındaki yerine işaret eder (Nurjekeul1, 2018; 20, 217, 290).

Nurjekeulı romanda özellikle eğitim meselesi üzerinde durur. Dil de bu mesele için hayatî bir öneme sahiptir. Kazaklar ve onların dili Kazakçanın da genel Türk kimliği içerisinde ele alınabileceğini kahramanı Tazabek'in ağzından söyleten yazar, Kazakçayı diğer Türk dillerinden daha müstesna bir yere koyar ve onu sistemli hâle getiren Ahmet Baytursunoğlu'nu över:

"Tazabek'in eğitim alırken tanıdığı bir diğer Kazak Ahmet Baytursunoğlu idi. Kelimeyi doğru yazmaya 'imla' diyordu. Onun dediğine göre 'imla'nın dilin kurallarına göre yapılması gerekir, dili ise zorla imlaya bağlamamak gerekiyormuş. Kırgız, Özbek, Türkmen, Tatar, Başkurt, Nogay hepsinin dili Türktür ve onların içindeki en düzgün Türk dili Kazakların diliymiş. 'Köpeğin kötü' denince alınan Kazak bununla nasıl övünmesin. Arap alfabesiyle yazılan yazıyı tüm Türk halkına öğreten o kişiymiş.” (Nurjekeulı, 2018; 262)

Nurjekeulı, Kazakçanın Kazak kimliğinin ayrılmaz bir parçası olduğunu düşünür. Kendisiyle yapılan bir röportajda devlet yönetimindeki Kazakların Kazakçayı kullanmadıklarından şikâyet ederek onları Rus olmakla suçlar. Günümüz Kazakistan devletini Rusça konuşan Kazakların yani dolaylı olarak Rusların idare ettiğini savunur:

"Birçoğunun 'Kazak dili için ölüyoruz ve Kazakça dilini geliştirmek için canımızı veriyoruz.' şeklindeki sözlerinin hepsi yalan. Kazakça günümüz Kazakistan devletini idare ederken bile kullanılmayan bir dildir. Kazakistan Devletinde hiç kimse devlet idaresinde Kazakçayı kullanmıyor, yetkililer Kazakça konuşmuyor. Bu yüzden hâlâ Rusya tarafindan yönetiliyoruz. Bu gerçekleri söylediğimde onların hoşuna gitmiyor."

(https://adebiportal.kz/kz/news/view/19006 15.02.2019).

Romanda 'Kazak kimliği’nin temel unsurlarından biri de şiir ve müziktir. Toplumların özellikle müzik kabiliyeti içine doğdukları toplumun kültür ortamı tarafından şekillendirilir. Müzik, en az dil kadar toplumların hafızasını ve hayatını içerisinde barındıran bir kimlik unsurudur (Köseoğlu, 2013; 22). Esasen Kazaklarda özellikle sözlü şiir, müzikle birlikte en çok kullanılan sanattır. Bu toplumda dombıra çalıp şarkı söyleyemeyen, irticalen şiir okuyamayan yok gibidir (Altınmakas, 2014; 23). Bu husus, romanın Rus kahramanı Kobzev tarafından da dile getirilir: “Türkü söylemeyen, şiir yazmayan Kazak yoktur.” (Nurjekeul, 2018 ; 218) Bu anlamda daha ilk sayfalardan başlayarak çeşitli vesilelerle dombıra eşliğinde Kazak şiiri ve müziği; romanın arka planında 'aşk', 'ayrılık', ‘ölüm' duygularına eşlik eder. Hemen her türlü acı ve zalimce tablo bu müzik eliyle onarılmak istenir gibidir.

Romanda kullanılan türküler yoluyla Kazak Kimliğini oluşturan tarihi olaylara da telmihler yapılır. 'Şaltabay'ın türküsü üzerinden (Nurjekeulı, 2018; 195, 222, 223) roman kahramanı Tazabek ile kan bağı daha önce açıklanan 'Tazabek Pusırmanoğlu' olayına gönderme yapılır (Nurjekeulı, 2018; 21). Esasında Tazabek karakteri geçmişteki bu karakterin esere bir yansımasıdır. Rusların 19. yüzyılda gerçekleştirdiği işgal hareketine Ulu Cüz'ün Alban koluna mensup Kazaklarının Aksakalı Tazabek başkaldırır. Kendisine teklif edilen tüm makam ve idari görevleri reddederek 1871 yılında Doğu Türkistan Hanı Elehan'a sığınır. Ruslar bu duruma tepki gösterip Doğu Türkistan Hanlığına savaş açar. Başlarda Rus saldırılarını püskürten Kazak ve Uygur Türkleri Ruslarla anlaşan bazı hainlerin fitneleri ve çıkardıkları kardeş kavgaları neticesi zayıf düşerek bağımsızlık mücadelelerini kaybederler (Kaşgarlı, 2004; 248-249). Şaltabay o kahramanla birlikte hareket eden Savrık'ın kardeşidir. Savaşın kaybedilmesi sonrasında Tazabek öldürülür, Şaltabay da Sibirya’ya sürülür. Şaltabay 
bir batır olmanın yanı sıra bir 'akın' yani şairdir. Tazabek'in kişiliğinde Kazak kimliğini bayraklaştıran şiirler söyler. Kitapta bu şairden yapılan alıntı ile Kazak kimliğinin bağımsızlığından ödün vermeme ve diğer Türk halklarıyla birlik içinde hareket etme özelliğinin altı çizilir.

Romanda 'Sopıya' olarak anılan Rus kızın okuduğu 'Beş Karaker' şiirinin şairi 'Ködek Maralbayulı' da Alban Kazaklarının iyi tanıdığı bir şairdir. 1888 yılında Almatı'da dünyaya gelen ve 'Ateş Ağızlı' şair olarak da bilinen Ködek, gerçekçi şiirleriyle tanınır. Sovyet devrimini açıkça eleştiren bir isim olan Ködek, kendisine zulüm ve baskı uygulanmasına rağmen doğru bildiklerini söylemekten vazgeçmez (https://turkystan.kz/article/56568-a-yn-kdek-bajshy-an-lyna-120-zhyl 18.02.2019). 1937 yılında öldürülen isimler arasında yer alan şairin kitaptaki varlığı, Kazak Türklerinin her şartta ve ortamda doğrudan yana olma özelliğini vurgulamaya dönüktür. Onun şiirlerinde anlatılan Kazaklara has hayattır ve bu hayatı bir Rus'un ağzından duymak Kazakları şaşırtır (Nurjekeulı, 2018; 17, 18). Çünkü bu türkü ve onun temsil ettiği tüm kıymet Kazak kimliği’ne aittir.

Müzikle ilgili romanda geçen bir diğer isim de Pişan'dır. Şair, icracı, şecere okuyan, pehlivan, nişancı ve şarkı sözü yazarı olan Pişan, Jalmen adında çok zengin bir beyin oğludur (Nurjekeul1, 2018; 248-249). Roman kahramanı Kapez kendisi de babası gibi bey olan Pişan'1 bir düğün vesilesiyle gittiği yerde anlatır. Buna göre Jalayır soyundan Bayşegir'den olan Pişan'ın yaşı o tarihlerde yaklaşık otuz üç, otuz dörttür. Marifetli bir akın olan Pişan atışmalara da katılır. Büyük bir dügünnde sırayla türkü söyleyen Aşirkül ile Zeynep isimli kızlarla atışmaya başlayan Pişan, atışmanın sonunda kızlar Cengiz Han soyundan olduklarını söyleyince edeple sözüne son verir (Nurjekeulı, 2018; 208-209). Roman içerisinde adı en sık geçen şair Pişan'ın 'Dünya Şirkin' isimli şiiri söylenir. Sonrasında zengin bir beyin zengin oğlu olmakla ve halkı servetiyle sömürmekle suçlanıp kurşuna dizilir (Nurjekeulı, 2018; 258). Pişan; gerçekleri söyleme ve hayata kıymet vermeme, bilgili ve edepli olma yönleriyle Kazak kimliğinin olumlu kıymetlerini temsil eder.

Roman kahramanı Kapez Bayğabıloğlu ve 'Sırğalı Erkemin' şairi Şanşar da Kazak halkının sağduyusunu yiğitliğini, cesaretini temsil eden isimlerdir. Şiir ve müzik Kazaklar için hafızadır, hayattır ve hayaldir. Sadece eğlenceli ortamlar da değil, en sıkıntılı zamanlarında da yüreğine gerçek bir 1stırap düşen bir Kazak herkes adına türkü söyler (Nurjekeulı, 2018; 127). Böylece acının adı konur. Bu şekilde acıya karşı kendisini savunmak daha kolay olur.

Kapez söylediği türkülerle Kazakların görkemli geçmişini temsil eder. Kapez Kazak kimliği'nin ilmini, sanatını ve aklını esere taşır. Esere de ismini verdiğini düşündüren 'Dünyaay’ koştasu ve halkının sıkıntılarını anlattı̆ğ 'Ağır gün-ey' şiiri ile hayatın içerisinde bir kahramandır. Eserde yer verilen türküler genellikle hüzünlü türkülerdir. Ağırbaşlı ve kalbe dokunan bu türkülerle olan biteni anlamlandıran Kazak halkı için türküsüz bir tören düşünülemez. Kapez, Sovyet rejimi tarafindan tehlikeli bulunur ve 1939 y1lında sürgünde ölür (Nurjekeul1, 2018; 315).

Romana göre müzik, doğuştan gelen bir yetenek olmakla birlikte gelişimi için eğitime ihtiyaç duyar. Kapez sevdiği kızdan ayrılmak pahasına İstanbul'a bunun için gider. Tazabek, Kapez'in yanına çırak olarak aldığ ' Karatay' isimli çocuğun mutlaka eğitim alarak kendisini geliştirmesi gerektiğini söyler (Nurjekeulı, 2018; 261). Romanda 'Baken' dışında şark1 söyleyen tüm isimler Kazak Kimliğinin olumlu yönlerine işaret eden kişilerdir. Müzisyen ve şair olmak, aydın olmakla aynı şey olarak değerlendirilir. Bu sanatı icra edenler sadece aydın değil, aynı zaman da milleti ve doğru bildikleri uğruna canlarından vazgeçecek kadar cesur birer kahramandır. Eserin sonunda Şeyi'nin Oralbek'ten kalan bir hatıra olarak andığ 1 torunu 'Kavsar' da müzisyendir (Nurjekeulı, 2018; 272). O da 18 Aralık Almatı olaylarında 
Kazakları bir Kazak liderin yönetmesi için sokağa çıkan gençler arasındadır (Nurjekeulı, 2018; 308). Bu sebeple zulüm görür ve bazı Kazak hocaları tarafından da aşağılanır. Ama doğru bildiğini yapmaktan çekinmeyen bir karakteri vardır.

Müzisyen olarak eserde yer verilen Baken ise olumsuz bir karakterdir. Bu sebeple okuyucu onun ciddi bir eser seslendirdiğine şahit olmaz. Komik ve kıymetsiz şarkılarla şahsiyetini sergiler. Onun üzerinden Türkiye Türklerinin müzik zevki de kısmen ötekileştirilir ve tenkit edilir (Nurjekeul1, 2018; 212). Sürekli hainlik eden ve bencil bir karaktere sahip olan Baken, bu sebeple Kazak kimliği içerisinde düşünülmez.

Eserde müzik, Kazaklar için aynı zamanda bir zaaf gibi ele alınır. Bazen türkünün ezgisinden sözün anlamına inemeyen Kazaklar, Rusların sözlerindeki ezgiyle de aldanırlar. Kendisine yumuşak ve ahenkli konuşan herkesi dost bilip ne söylediğine dikkat etmezler. Bir ninni sahnesinden hareketle bu mesajı veren yazar, birçok yerde olduğu gibi burada da Kazak halkını saf olmak yönüyle tenkit eder (Nurjekeulı, 2018; 164). Kazakların dini anlayışı da buna benzer bir özellik gösterir. Şeyi, Kapez ailesi için Kuran okurken işittiği sözleri anlayamaz ama sözlerin ezgisindeki kudrete teslim olur (Nurjekeul1, 2018; 199). Fakat buradaki durum tenkit konusu yapılmaz. Yazar bu durumu olağan kabul eder. Çünkü Kazak kimliğinde din folklorik bir ritüel gibidir. Kuran okunur, dua edilir; fakat hayat din ekseninde biçimlenmez. Bu durumu yazar Kazak Kimliğini temsilen eserde yer verdiği Şeyi üzerinden şöyle ifade eder: "Şeyi itikatl fakat dindar değildi. ” (Nurjekeulı, 2018; 306)

Eserde, kahramanlara verilen isimler Kazak kimliği açısından oldukça önemlidir. Bu anlamda Tazabek'in 1923 yılında doğan üçüncü çocuğunun isminin 'Kenesbek' olması da oldukça dikkat çekicidir. Sovyet döneminin özgür ortamında doğduğu için Kazak tarihinin önemli bir ismi olan Kenesarı Han'ın ismi verilir (Nurjekeul1, 2018; 263). Yazarın bu isimlendirme üzerinden Sovyet dönemi hakkındaki olumlu değerlendirmesi kahramanlarının bir sürecin sonunda gerçekleri fark edip bilinçlendiğine işaret etmek; böylelikle önyargısız, realist bir tutum sergilediğine okuyucuyu ikna etmektir. Bir diğer sebep de o tarihte Sovyet Rusya için Çarlık Rusya'sının emperyalist bir devlet olarak tanınması ve Kenesarı Han'ın bu sömürgeci hükümete isyan etmiş olmasıdır. Kenesarı Orta Cüz hanlarından Abılay Han'ın en küçük oğlu Kasım Han'ın oğludur. Kazakistan'ın Kökşetav bölgesinde 1802 yılında dünyaya gelen Kenesarı, 1841-1847 yıllarında Orta Cüz'ün Han'1 olmakla birlikte bütün Kazakları idaresi altında birleştirmek için çalışır (Tansu-Özdemir, 2017; 211-212). Çarlık Rusya'sının sömürü düzenini reddeden tarihî bir kahraman Kazakların sömürü düzenine en başından karşı olduğuna işaret etmektedir.

Kazak kimliğinin önemli bir özelliği de tabiattır. Kazak, tam anlamıla tabiatın bir parçasıdır. Çadırda ve göçebe bir hayat süren Kazakların tüm hayatı tabiatın kucağında geçer. Tabiatın dilinden anlayan Kazaklar ona ait detayların bilgisine hâkimdir. Roman kahramanı Tazabek'in dağ ile ilgili değerlendirmesi bu anlamda dikkat çekicidir: "Dağın güzelliğini dă görmeyenler nereden bilsin? Dă̆ dediğin düz yerin üzerinde bir yükselti diye düşünülebilir. Dă̆ dediğin sadece yükselti mi? Kayası, kalın çam ăgacı, birbirine eklenen çalılar, pınarları, uçurumu, otu ile çiçeği hayvanı ile kuşu bu hayatın hiçbiri başka yerde olmayacak, başka yerde bulunamayacak kadar muhteşem!" (Nurjekeul1, 2018; 88)

Eserde tabiat, Kazak kimliğinin o kadar önemli bir unsuru olarak değerlendirilir ki Kazak insanı onlara benzetilerek anlatılır. "Başkalarının bilmediğini bilen, görmediğini gören insanlar da dăg gibidir belki. Rahmetli babası da öyleydi!'” (Nurjekeulı, 2018; 88-89) Dağ dışında Kazak insanı cesareti, doğruluğu ve birlik halinde oluşu bakımından çam ağacına da benzetilir: "Her çam ăgacı birleşince yeri göğ̈̈ devirecek gibi olurdu. Öyle kudret diğer ormanda yoktur. Çam ăgacı ne eğilir ne bükülür, sadece sallanır. Dümdüz büyür ve dik 
durarak ölür. (...) O tarafta Kapez, burada Kitapbek, kurşunlanan Pişan hepsi ayrı bir çam ăgacıdır." (Nurjekeulı, 2018; 266) Kazakların çama benzetilmesi yazar için ideal olandır. Mevcut durumda çam tabiatlı Kazaklar olsa da bunların sayısı azdır ve birlikleri eksiktir: "Çam ăgaçlı ormanın yanında otursa bile Kazakların çam ă̆acı gibi olamayışına sinirlendi." (Nurjekeul1, 2018; 266) Kazaklar için zaman da bir tabiat unsuru olan rüzgâra benzer (Nurjekeul1, 2018; 266).

Kazaklar, hayatlarını hayvancılık yaparak sürdürürler. Hayvancılık yapmak demek de tabiatı gereği gibi tanımak demektir. Hemen her Kazak, geçimini hayvan bakarak sağlamaktadır (Nurjekeulı, 2018; 230). Kazak halkının kıtlık zamanında yaşadığı ağır kayıpların sebebi de hayvanlarının elinden alınması yani tabiatla irtibatının koparılmasıdır (Nurjekeulı, 2018; 299). Tabiatla arası iyi olan Kazakların, zamana yine tabiat üzerinden ayak uydurmaları sağlanır. Bu anlamda roman kahramanı Tazabek Ruslardan tarım faaliyetlerini öğrenir. Hatta bir de "Tayken Toğan” olarak adlandırdığı sulama kanalı açar (Nurjekeulı, 2018; 264-265).

Kazak Kimliğinin en temel unsurlarından biri de şereftir. Şeref; "Bir kimsenin gördüğü saygının dayandığı mânevi yücelik, onur, haysiyet (Topaloğlu, 2014; 1182)." şeklinde tanımlanmaktadır. Yani Kazak toplumunun her bir ferdi saygıyı hak edebilmek için yaşar. Esasında katlandığı her sıkıntıya 'şeref' için katlanır. 1916 yılında Ruslara asker verme tartışmaları sırasında yapılan tartışmalar esnasında Kazak yönetici Jakıpberdi Kazaklara şöyle seslenir: "Benim görevim, Rusların öldürdügü Tazabek atalarımızın da Avbakir kardeşimin de intikamını almak değil, horlanan Kazakların şerefini korumak! Hepimiz bugün şerefimiz için toplandık, onun için ata bindik!” (Nurjekeul1, 2018; 52)

Kazaklara göre saygın olmanın şartlarından biri 'ahde vefa' yani ne pahasına olursa olsun verdiği sözden dönmemektir. Şeyi’nin ağabeyi Ağıntay, babası Tilevli’yi Ruslarla savaşmaktan vazgeçirmeye çalışır. Babası onun 1srarına: "Ne olursa olsun halkla birlikte yaşayacağız. Öyle yapmazsak 'andı bozanı ant çarpar oğlum!” (Nurjekeulı, 2018; 45) şeklinde cevap verir.

Saygın olabilmenin yani şerefli kalabilmenin bir diğer şartı kadirşinaslıktır. Nitekim romanda Çin'e kaçış yolunda kendisinden haber alamadıkları Serikbay'ı aramak için gönüllü olan Nüsipbek Kazakların kadirşinaslığına örnek bir roman kahramanıdır: "Serikbay’ı ben araştırıp geleyim. O benim kardeşim ve yaşıtız. Onu ben aramazsam başka kim arar? Ölürsem ölürüm, onun canı benim canım kadar önemlidir." (Nurjekeulı, 2018; 93) Fakat kadirşinaslık başkasını kendisine minnetle bağlamak da değildir. Bu sebeple Kazak yaptığı iyiliği başa kakmaz ve o iyiliği karşılık bekleyerek yapmaz. Tazabek bir diğer roman kahramanı Tabay'la ilgili olarak: "Bir kere iyilik yaptı diye onu avucumuzda tutarsak bunların ne günahlarl var? O da kendisi gibi Allah'ın bir kulu değil mi? ” (Nurjekeulı, 2018; 195) şeklinde düşünür.

Kazak kimliğinde vatan sevgisi de önemli bir unsurdur. Kazaklar başlarına gelen tüm sıkıntılara bu sevginin verdiği güçle karşı durur. Vatan sevgisi tüm sürgünlere, kıyımlara rağmen onları ayakta tutan güçtür. Kazaklar için 'vatan' sadece yaşamak için değil ölmek için de güzel ve gereklidir: “Bu kadar eziyete, açlı̆̆a dayanmalarının sırrı, sadece doğduğu topră̆a yetişip doğduğu toprakta ölmek arzusuydu (Nurjekeul1, 2018; 131)." Kazaklar vatan söz konusu olduğunda diğer tüm kavga ve kırgınlıkları bir kenara bırakıp düşmana karşı topraklarını savunmak için canını ortaya koyar. II. Dünya Savaşı'nda Alman saldırısına karşı Sovyet Ruslarla birlikte vatanlarını ölümleri pahasına korurlar (Nurjekeulı, 2018; 297).

Misafirperver bir halk olan Kazaklar misafirlerine ellerindeki en kıymetli yemekleri ikram eder (Nurjekeulı, 2018; 201). Kazaklardan birinin başına gelen bir sıkıntıda diğer kazaklar tam bir kardeş gibi yardıma koşar (Nurjekeulı, 2018; 229). Yine misafirine ikram 
etmek ve gerektiğinde diğer Kazak kardeşine yardım etmek için Kazaklar çok malın olmasını ister. Kazaklar misafirin ya da ihtiyaç sahibinin kim olduğuna da bakmazlar. Gerektiğinde bir Rus'a da evlerini, sofralarını açıp, imkânlarını paylaşırlar: “Köpzip ilk defa Moskova'dan geldiğinde Bayğabıl onun ailesine bir yıl bakmış. Adam bir ineğini vermiş, giyeceğine, içeceğine her şeyine yardım etmiş. " (Nurjekeul, 2018; 146)

Çok malın elde edilmesi ve korunması için de nüfusun çok olması gerekir diye düşünürler. Malın ve çocuğun çok olmasına sevinirler ve bunlarla övünürler (Nurjekeulı, 2018; 251). Kazak toplumuna göre çokluk kuvvettir. Kazakları düşmanları ilk önce nüfusunu azaltarak zayıflatır. Bu sebeple yapılması gereken ilk şey çoğalmaktır: "Kazakların yapacă̆ ilk şey, her nasıl olursa olsun çoğalmaktır. (...) 1916 en ağır, en zorlu yıldı, Kazaklar çok azalmıştı. Çarın buyruğuna karşı çıktı diye bahaneler uydurup suçluyu da suçsuzu da öldürdüler. Kadın erkek, çoluk çocuk demeden hayvanları bile öldürdüler. Işste bizi azaltmak için yeryüzünden yok etmek için kırdılar. ” (Nurjekeulı, 2018; 162)

Kazaklar soyun devamına oldukça önem verir. Roman kahramanı Tazabek'in babası Ömerali, oğlunu evlendirmek için bu sebeple acele eder (Nurjekeulı, 2018; 35). Şeyi, ağabeyi Ağıntay’ın oğlu Samen'in çocuklarının vefatı sebebiyle onun soyunun kesileceğinden endişe eder (Nurjekeulı, 2018; 296). Soyun devamı sadece bir ailenin değil milletin ayakta kalması için gereklidir. Şeyi ve Tazabek arasındaki bir diyalog bu hususun önemine işaret eder: "Erkekler kadını ne için korur biliyor musun? -Çünkü kadın evlat verir. -Peki, evlat için neden canını verir? -Çünkü o sadece kendisi için değil, halkı için de değerlidir. $O$ ne kadar mütefekkir olsa da evladı olmayan halk er ya da geç yok olmaz mı? -Evet, öyledir. Allah bizi yok olmaktan korusun!" (Nurjekeul1, 2018; 166-167)

Kazaklar için soyun devamı demek, devletin gelişmesi demektir. Bu sebeple çocuğu koruyup yetiştirmek, torun büyütmek çok sorumluluk gerektiren ve kıymetli bir iş olarak görülür:

"Torunlar ve torunların evladının mürüvvetini görmek Kazaklar için her şeyden önemliydi. (...) Torunu ile torun evlatlarını kucă̆ına alıp koklamak anne ile ninenin önündeki hayatın en muhteşem olaylydl. O koku, insana sonsuz hayat veren yeryüzündeki en güçlü ilaçtır. Bu ilacı ne okumuş insan ne ulema yapabilirdi. Çünkü onu Allah'ın kendisi yapmıştı." (Nurjekeul1, 2018; 304)

Kazaklarda sadece büyükler küçükleri kollamaz, küçükler de hayatlarının her noktasında büyüklerine saygıda kusur etmezler. Büyükler küçükleri yetiştirirken onlara adalet başta olmak üzere cesaret, kanaat ve aklı kullanma gibi hasletleri öğretir. Büyüklerin varlığı küçüklerin hayatına bir nizam ve ahenk verir. Tazabek annesi Kalişa'yı kaybedince bunu daha net anlar: "Oralbek, Şeyi ve Tazabek hepsi birbiriyle irtibatı kopmuş akrabalar gibi oldu. Sanki onları uyumlu hale getirip bağlayan ince ipi rüzgâr koparmış gibiydi.” (Nurjekeulı, 2018; 231)

Kazaklar ancak güçlü liderlerin arkasında güçlü olabileceklerine inanır. Yaşadıkları sıkıntıları ve zayıflıklarını aralarında birliği tesis edecek güçlü bir liderin olmayışıyla açıklarlar. Zira Kapez'in de dediği gibi: "Başkanı akıllı olanın halkı da akıllı olur, başkanı zayıf olanın halkı da zayıf olur." (Nurjekeul1, 2018; 222) Cüz ve uruglara ayrılmış çok parçalı bir toplum olan Kazaklarda devlet idare etmekle akraba ilişkilerini sağlıklı yürütmek arasında da çok bir büyük bir farklılık yoktur. Zira her urug ve onların bağlı bulunduğu her cüz küçük bir devlet gibidir. Tazabek bu sebeple akrabalarının evlatlarını da kendi evlatları gibi görüp gözetmeyi bu küçük devletin dizginlerini elinde tutmak için kendisine bir borç ve genel olarak Kazak kimliği için 'en güzel haslet’ olarak kabul eder (Nurjekeulı, 2018; 305). 
Yazar, eserde roman kahramanı Tazabek'i rastgele hareket ettirmez. İsmini de özenle seçtiği kahramanın kuru bir intikam hırsının esiri olmasına izin vermez. Tazabek hakkı olandan fazlassının peşine düşen bir açgözlü de değildir. O gelişmeye ve yeni şeyler öğrenmeye uzak, sabırsız, sır tutamayan ve zayıf biri de değildir. Tüm Kazakları temsil edecek şekilde kurgulanan roman kahramanı tam aksine aklıyla düşünen, kanaatkâr, sabırlı, gelişmeye, öğrenmeye açık, ağzı sıkı ve güçlü biridir.

İdeal bir Kazak insanı gibi biçimlenen Tazabek diğer tüm Kazaklar gibi haksızlığa, zayıfın ezilmesine de rıza göstermez. Fıtrat itibariyle savunmasız olan kadınların toplum tarafından suçları olmadığı halde gördükleri zarar sebebiyle aşağılanıp dışlanmalarına izin vermez. Göç sırasında kendisinden yardım isteyen herkesle elindeki imkanları paylaşır. Can düşmanı olan ve sonunda kendisini öldüren Rus'un kırılmış bacağını bile tedavi edip onu evine kadar bırakır. Misafiri olduğu bir düğünde bir çocuğun haksız yere zulüm görmesine de göz yummaz. İyi niyetle nefsi müdafaa yapan Tazabek, her ne kadar kaybediyor gibi görünse de temsil ettiği kimliğin en sonunda kazandığı görülür.

Şeyi 24 yaşındayken kocası ve romanda Kazak kimliğini temsil eden ideal kahraman Tazabek öldürülür. 61 sene sonrasına sıçrayan roman zamanı Şeyi'nin geçmiş günleri anmasıyla sürer. Şeyi, Tazabek'siz geçen ve geçecek bunca yıllık ömrü onu anlatmak ve hatırlatmak için yaşadığına inanır. "Zaman her şeyi çözer, diye avunuyordu halk. O dediğin çözüm sadece unutmaktır fakat unutmak ibret değil unutmamak ibrettir. Babalarını unutan insanı, nesli de unutmaz mı? Şeyi de ölürse Tayken 'in karmakarışı hayatını evlatlarına kim anlatırdl? (Nurjekeulı, 2018; 273)” Tazabek'in anlatılmasından maksat Kazak kimliğinin olumlu örneklerinin tarihi akış içerisinde nesiller arasında yaşatılmasıdır.

Eserde 'Kazak kimliği' en geniş anlamdaki insanî ilkelerle temellendirilen bir kültür zemininde tanımlanmaktadır. Her ne kadar zulüm görmenin neredeyse tek sebebi Kazak kimliğine sahip olmaya indirgense de (Nurjekeulı, 2018; 143) barışsever, adil ve huzur içerisinde yaşamanın Kazak olmakla değil, insan olmakla mümkün olabileceği mesajı verilir. Allah herkese Rus, Kazak diye bakmadan hayat hakkı vermişken; herkes Âdem peygamber ve Havva anadan yaratılmışken insanlar arasında ayrım yapmak art niyetliliktir (Nurjekeulı, 2018; 254). Bu sebeple her ne kadar Kazak olsalar da Baken, Tunık’ın çocukları, Yönetici ve Kapez ile Kavsar'ın ölümüne sebep olanlar gibi olumsuz tipler 'Kazak Kimliği' dışında bırakılıp ötekileştirilirken Rus olmalarına rağmen Sophia, Kobzip, babası bir Rus olduğu halde Oralbek, aslı Kalmuk olmakla birlikte Davlatbey ve Kırgız Tabay 'Kazak Kimliği' içerisinde değerlendirilir.

Görenekli Kazaklar, kimliklerini inşa ederken huzur, adalet, barış ve kardeşlik ilkelerini esas alır. Nitekim Kazaklara göre çoğu zaman kötü olan sistem ya da hükümet değil, o sistemi veya hükümeti temsil eden kötü niyetli insanlardır (Nurjekeulı, 2018; 194). Kötü niyetli insanlara mani olacak bir yasa yapmak da mümkün değildir (Nurjekeul1, 2018; 238). Kötülük de iyilik de insan tabiatının farklı farklı oluşundandır. Bir insanın Kazak ya da Rus olması onun peşin olarak iyi veya kötü olduğu anlamına gelmez. "Rusların hepsi Kobzev gibi olsaydı 1916 yılında koyunlara saldıran kurtlar gibi Kazaklara saldırır mıydı? (...) Bir Kazak Tazabek'i Kobzev gibi tam sevmeyebilir. İkisinin birbirlerine gösterdiği saygının kardeşlerinden üstün olduğunu Allah'tan başka kimse bilmezdi.” (Nurjekeulı, 2018; 283)

\section{Kazak Kadınının/Kızının Kimliği}

Beksultan Nurjekeulı'nın 'Ey, Dünya Ey!' romanında ana kahraman bir kadındır. Yazar, özellikle kadın hissiyatını ve hayatını isabetle anlatmakla tanınmaktadır. Bu eserde de kadın kahramanlar erkeklere kıyasla biraz pozitif bir bakışla ve daha ön plana çıkarılarak 
anlatılmaktadır. Genel olarak ana kadro ve figüran kahramanlar içerisinde yer verilen hemen hiçbir kadın olumsuz olarak verilmez. Olumsuz davranışlar içerisinde bulunan kadın kahramanların bu davranışları da şartlar ve zaman ileri sürülerek mazur görülür.

Romanda 'Kazak kimliği' içerisinde değerlendirilebilecek kadınların yeri genel olarak edilgen bir noktadadır. Ona yakıştııılan sıfatlar, kendisinin bir hak olarak kazandığı sıfatlar değil de daha çok kendisine bağışlanmış sıfatlardır. Düşmanın kötülük ettiği kadın, Tazabek'in bir lütuf gibi gösterilen anlayışlı tavrı sayesinde suçlanmaz; fakat Tazabek'in evli bir kadın olan Deneker'le keyfi olarak gönlünü eğlendirmesi de erkeğin başına gelecek basit gençlik hatası haklarından biri olarak meşrulaştırılır. Oysa bu iki şey aynı değildir. Kadının istismar edilmesi sahneleri romanın başından sonuna kadar belli aralıklarla tekrar edilen bir motif şeklinde verilir. Nihayet son kurban ninesinden sonra torunu 'Kavsar' olur. Bu durum Kazak toplumunda kadının hâlâ cinsel bakımdan istismara müsait ve zayıf olduğunu göstermektedir. Gerek savaş gerek düş̧man zulmü gerekse de sosyal ve siyasi ortam sebep gösterilerek bunlar karşısında kadının çaresiz, güçsüz ve savunmasız olduğu tezi işlenir. Romanda anlatılan ilk olayların başladığı 1916 yılından son olayın gerçekleştiği 1991 yılına kadar birçok şey değişir; ama kadının kaderi değişmez.

Yine eserde kadınlar erkekler tarafindan belli bir sebeple korunan varlıklar olarak anılır. Kadınların korunmayı hak edebilmeleri için erkeğe ve nihayet halkına evlat vermesi gerekir. (Nurjekeulı, 2018; 166-167). Kadın yine erkeklerin kendisine güvenip değer vermesini istiyorsa dürüst olmalıdır (Nurjekeulı, 2018; 79). Fakat buna karşl1ık erkek; 'düşmandan kalesini saklayan biri gibi' sır saklayabilen, (Nurjekeulı, 2018; 192, 243) halkının intikamını almakla görevli soylu biri olarak içindeki firtınaları gizleyebilen biri olmalıdır (Nurjekeulı, 2018; 103). Kadın erkeğine saygı gösterdiğinde esasında halkına saygı göstermiş olur (Nurjekeulı, 2018; 277). Kazak kadını romanda Rus kadınından farklı olarak kocasının her dediğine 'tamam' diyen biri olarak anlatılır (Nurjekeulı, 2018; 190).

Yine romanda Tazabek öldürülünce Şeyi, ölen kocasının kardeşi veya yakınlarından birisiyle evlendirilmesi geleneği 'amengerlik' gereği kocasının akrabası Kenjeğara ile evlendirilmek istenir. Bu teklif Şeyi'den önce Kenjeğara' ya yapılır; fakat o bunu kabul etmez. $\mathrm{Bu}$ sebeple durum Şeyi ile paylaşılır. Şeyi, Kenjeğara bir yana büyüklerinden bile böyle anlayışlı bir yaklaşım beklemediğini söyler. Sonrasında cesaretini toplayıp evlenmemeyi seçer (Nurjekeul, 2018; 274).

O dönemde yazılan farklı türdeki metinlerden hareketle Kazak kadınının evlenmesi meselesinde kararı babası başta olmak üzere kadın dışındaki aile bireylerin verdiği; kadının bir mal gibi alınıp satıldığı söylenebilir. Bu genel bilgiye karşılık Nurjekeulı eserinde gerçekleşen evliliklerin tamamında kadının rızasının alınmasını sağlar. Kitaptaki evliliklerin hiçbiri kadına rağmen yapılmaz. Evliliklerin sona ermesi de eşlerin ölümle gerçekleşir.

Roman kahramanlarından Kamza evlidir ve bu evlilikten üç kızı olur. Fakat soyunun devam etmesi için bir erkek çocuğunun olması gerektiğini söyleyerek hanımından ikinci evlilik için izin ister. Şeyi'ye soyunu sürdürecek bir erkek çocuk için kendisiyle evlenmesini teklif eder (Nurjekeulı, 2018; 283). Bu durum anlatıcı tarafından da yadırganmaz. Buna göre Kazak toplumunda kız çocuğunun soyun devamı için yeterli görülmediğini, erkek tarafından korunmak ve halkına hizmet etmek için kadının onlara vermesi gereken evladın erkek olduğunu anlamak mümkündür. Ayrıca çok eşlilik durumunun da olağan olduğu tespiti yapılabilir. Nitekim romanın en az Tazabek ve Şeyi kadar önemli kahramanlarından olan iyi eğitimli bir aydın, şair ve müzisyen Kapez de ilk karısı Jibek'ten sonra bir Uygur kıza âşık olur. Onunla da evlenmek ister. Jibek bu talebe rıza göstermemiş olacak ki evlilik gerçekleşmeyince barışırlar (Nurjekeul1, 2018; 300-301). 
Kazak kadınının kimliği ile ilgili olarak Tazabek üzerinden genel akıştan farklı bir diyalog paylaşılır. Kitapbek, Tabay ve Tazabek arasında taşınma kararına dair geçen bir konuşmada Tazabek; bu kararı tek başlarına alamayacaklarını, hanımlarıyla konuşmaları gerektiğini söyler. Bu beklenen ve alışık olunan bir cevap olmadığı için olsa gerek Kitapbek onu, şaka ile karışık 'kılıbık' olmakla suçlar (Nurjekeulı, 2018; 242).

Romanda Şeyi’nin bir gece önce Kazak bir yönetici tarafından istismara uğradığı ve bunun Şeyi için bile sıradanlaştığı bir tarihte 'Kadınlar Bayramı' ilan edilmesi oldukça ironiktir. Kadından alınan tüm mukaddesine karşılık, o gün kendisine verilen yeni haklar ya da özgürlükler değil sadece bir defterdir.

Kadınlar gerekli, kız çocukları ise erkek çocuklarının içerisinde ve özellikle bir tane olmak kaydıyla güzeldir (Nurjekeulı, 2018; 207). Bu sebeple olacak Tazabek'in de iki oğlu ve neredeyse sadece adının Gülsan olduğu, liseyi bitirdiği ve kocaya kaçtığı söylenen bir kızı vardir.

Şeyi romanın başkahramanıdır ve hemen her şey okuyucuya onun gözünden aktarılır. Kazak kadının kimliğinin yengesi Jüzük ve kayınvalidesi Kalişa ile birlikte en ideal örneklerinden biridir. Dikkati çeken en önemli ortak özellikleri fedakâr, çalışkan ve itaatkâr oluşlarıdır. Hemen hepsi eğitimin ne kadar önemli olduğunu iyi bilir. Hayat pratiği konusunda inisiyatif alan ve özellikle aile içerisindeki hayatı idare eden konumundadırlar. Şeyi eğitimini ilerletip öğretmen olmayı da başarır. Fakat romanın sonunda 'Kavsar'ın yaşadığı trajedi, okuyucuda Kazak kadınının onca yıllık birikimini bir kalemde kaybederek romanın başındaki noktadan bile geriye düştüğü hissi uyandırmaktadır. Zira 1916 yılının göçebe hayatında, eğitimsiz Kazak toplumunda doğup büyüyen Tazabek, düşmanın istismarına uğrayan eşine kayıtsız şartsız sahip çıkarken, 1985 yılında yani yaklaşık 70 sene sonra eğitim ortamı gelişmiş, yerleşik hayata geçilmişken üstelik bir üniversitede hoca olan bir Kazak öğretmenin düşman tarafından istismara uğrayan bir genç kıza sahip çıkmak yerine onu aşağılaması düşündürücüdür.

Romanda erkeklerden farklı olarak Kazak kadını ile çatışan bariz bir 'öteki' yani Rus kadınından bahsetmek mümkün değildir. Romanın girişinde anlatılan Sophia, Kobzev'in karısı ve Sergeyçük'lerin hanımları da dahil tüm Rus kadınları ya Kazak kimliği içerisinde olumlu tiplerdir ya da nötr olarak verilirler.

Romanda anlatıcı ve merkez kahramanın bir kadın olması, yine genel olarak olayların kadınlar etrafında dönmesi yazar tarafından özellikle istenir. Zira roman, Kazak toplumunun zulme ve soykırıma uğradığı bir dönemi konu edinmektedir. Bu çeşit bir acının ve zulmün yazılı bir eserde gözle görülürcesine müşahhas anlatılabilmesi için en ideal kahraman kadrosu ağırlıklı olarak çocuklar ve kadınlardan oluşmalıdır. Böylelikle 'kendi' kimliği üzerinden ‘öteki'ni ve onun tabiatını daha net göstermek mümkün olabilir.

\section{Kazak Kimliğine Yönelik Eleștiriler}

Nurjekeulı eserinde kahramanların aralarındaki diyalogları ve kimi olayları kullanarak 'kendi' imajına dönük eleştiriler yapar. Eser, geçmişin bugüne göre daha iyi olduğu tezini işler (Nurjekeulı, 2018; 36, 261, 310). Bugün hayatın ve insanın geçmişe göre daha kötü olmasının ‘öteki’ yani düşman Ruslar dışında Kazaklardan kaynaklanan sebepleri de vardır. Kazak halkı eserin anlattığı dönemde olup bitenlerle ilgili olarak iki temel başlıkta eleştirilir: eğitimsizlik ve birlik kuramama.

Kazak halkını daha eserin başında Şeyi, babası üzerinden eleştirir. Zamanın şartlarına uyum sağlayamamış, "kimseye benzemeyen, masallarda yaşayan ilkel bir halkın kalıntısı gibi bir halk (Nurjekeulı, 2018; 37) olan Kazakların en büyük sorunu eğitimsiz oluşudur. Buna 
karşılık eğitim almak isteyen ya da eğitim için halkına destek veren hiç kimse yoktur. Kazaklar; eğitimlisi az, cahili çok bir toplum halindedir. Türkiye'de eğitim alan bilgili Kapez ile Tazabek üzerinden Kazakların bu eksikliği üzerinde durulur. Kapez bu konuda şu tespitleri yapar:

"Bizde eğitim alan bilgili, zeki kişi çok azdır. O yüzden birbirimizi dinlemiyoruz, düşünmüyoruz. (...) İşte bu suç kendimize aittir, kendimizin okuması gerekir, çocuklarımızı da okutmamız gerekir. Fakat çocuklar eğitim alsın diye hangi Alban'ın zengini okul yapar? Bilmiyorsun, ben de bilmiyorum. Yaşamak için zenginlik gerekir fakat güçlü halk olmamız için ilk önce eğitim şarttır. Gözü açık halkla herkes anlaşabilir. Cahil halkı herkes kandırır, kimse önemsemez.” (Nurjekeul1, 2018; 163)

Yazara göre birlik olamama da dahil olmak üzere Kazak halkının her probleminin temeli eğitimsizliğe dayanmaktadır. Kazaklar göçebe olarak yaşadıkları ve Rus tehlikesinden uzakta bulundukları dönemlerde sadece hayat pratikleri, iyi niyetleri ve cesaretle savaşmaları sayesinde her şeyin üstesinden gelmektedir (Nurjekeulı, 2018; 221, 239, 261, 276). Fakat artık zaman ve şartlar aynı değildir. Kitapbek eğitimsiz Kazaların sadece düşmana değil kendi halkına da cehaletleri ile zarar verebileceklerini bir dağ metaforu ile anlatır:

"Eğitim gören insan cahil insandan daha yüksektir. Yüksekte olan kişi yükseği de görür. Dağın tepesindeki kişinin gördüklerini dağın dibinde duran kişi göremez. Fakat ikisi de 'Biz dağda oturuyoruz.' derler. Bazen dağın eteklerinde oturan dağın tepesinde oturana firsat vermez. 'Zekiyi aptal kırar.' sözünde olduğu gibi.” (Nurjekeulı, 2018; 221)

Eğitim bilginin ve tarihin yazı ile kayda geçmesini sağladığı için de önemlidir. Kazaklar eğitim meselesinde gereken çabayı göstermedikleri için kaybettikleri her insanla birlikte geçmiş tecrübe ve bilgi birikimlerini de yitirmekte, yeni şeyler de ögrrenememektedir. $\mathrm{Bu}$ durum onları bilgiyi yazıyla koruyan ve gelişimini sürekli hale getiren Ruslar karşısında zayıflatmaktadır. Kitapbek Tazabek ve Kobzev'le bir tartışma sırasında bu konuda şunları söyler:

"Bizim Kazakların ilmi aklında, herkes onu birbirimizden sorarak öğrenir, soramadıklarını yaşar öğrenir. Rusların ise ilmi kâğıtta, onu sadece okuma yazma bilen kişi öğrenir. O yüzden Ruslar çoğaldıkça bizim bildiğimiz azalıp hayatın ve yasanın sırrı da çoğalıyor. Rusların kâğıttan öğrendiğini Kazaklar öğrenemiyor.” (Nurjekeulı, 2018; 239)

Okuyamayan, yazamayan eğitimsiz Kazak halkının kendi devlet sistemlerini kurup kendi yasalarını yaparak kendilerini yönetme, modern usullerle savaşan düzenli bir ordu kurma gibi bir imkanları olmadığı gibi Rus yasalarında sınırlı da olsa kendilerine tanınan hakları bilme, suçlu olup olmadığı konusunda yasalardan hareketle savunma yapabilme şansı da yoktur (Nurjekeulı, 2018; 163-164). Kazakların cahilliği onları siyaset ilminden de nasipsiz bıraktığı için Ruslar onları sürekli aldatmıştır (Nurjekeulı, 2018; 193). En kötüsü görkemli ve bereketli tarihleri de soykırım, kıtlık, savaş gibi sebeplerle ve hızla yok olan insanlarla birlikte yok olmaktadır: "Kazakların tarihi yoktur, sözündeki gibi zamanı zaman yapan insanı da olmamış. Çünkü yazdırmadı, konuşturmadı. Onun evvelki hayatı günümüzden ileriydi.” (Nurjekeul1, 2018; 310-311)

Yazar, Kazak toplumunda geçmişte uygulanan eğitim sistemini de inceden inceye eleştirir. Eserde kahramanlardan Tazabek ve Kitapbek mollaların eğitici olarak ders verdiği eğitim sisteminde kısa sürede olsa ders alır. Fakat bu eğitim biçimi kıskançlık, dedikodu, fesatlıkla dolu bir ortamda oldukça otoriter koşullarda verilmektedir. Bu konuda Kitapbek şunları söyler: "Ben molladan sadece iki hafta ders almıştım. Bundan ben mi suçluyum yoksa hemen çubuğunu kaldıran molla mı Allah bilir. Fakat ilim alan kişinin her sözü bedenimi ürpertiyor.” (Nurjekeul1, 2018; 253) 
Eserde eleştiri konusu yapılan ikinci husus birlik olamamaktır. Esasen bu sorun da daha önce söylendiği üzere cehalet kaynaklıdır. Eğitim alamadığı için kendini geliştiremeyen ve kim dost kim düşman bilmeyen saf Kazak halkı basit sebeplerle birbirine düşmektedir. Kıskançlık, ihanet, korkaklık ilmin olmadığı yerde çoğalan belâlardandır (Nurjekeulı, 2018; 262). Cüz ve uruglardan oluşan parçalı bir yapıdan oluşan Kazak halkı söz dinletecek, akıllı, eğitimli ve cesur bir lidere sahip olamadığı için herkes bencilce sadece kendisini düşünür. Bir araya gelemedikleri için de düşmanlarına kolayca teslim olurlar ve zulme uğrarlar. Yazar eserde bu tespiti Kitapbek’e söyletir:

"Kazaklar, aralarındaki başıboşluğa son vermezlerse hiçbir zaman devlet olamazlar. Biri diğerini kötüler, kıskanır. Birisi ileri geçince diğeri onu düşürmeye çalışır. 'Niye öyle yaptın?' dense o hemen kinlenir. Benim düşünceme göre bu da savaş sayılır. Böyle kendi aralarında savaşırken ilerlemeleri mümkün mü?” (Nurjekeulı, 2018; 253)

Eserde Kazaklar birlik kuramadıkları için eleştirilirken yazarın özellikle Ulu cüze bağlı bir urug olan Albanları öne çıkarması, 1916 olaylarında coğrafi konumları sebebiyle daha çok onların eziyet çektiğini vurgulaması ve bu uruğun kaderini, acısını ve hikâyesini genel Kazak toplumu ile yarıştırır gibi ayırması oldukça dikkat çekicidir (Nurjekeulı, 2018; 37, 163). "1916 yılındaki soykırım Albanlar yaktıysa 1932 yılındaki açlık tüm Kazaklart yıktı." (Nurjekeulı, 2018; 296) Ulu Cüz'e bağlı en eski uruglardan biri olan Albanlar Tazabek’in ataları, Sophia'nın sahiplenmesi üzerinden öne çıkarılır: "Kazakların geliniyim ve Kojak'ın karısıyım. Alban'ım, Sofiya'da değilim, Sopıya'yım.” (Nurjekeulı, 2018; 66) Romanın Kazakların düşmana karşı zayıf olmasının temel sebebini bir olamamak olarak vurgulamasına karşılık bu mikro ölçekli urug vurgusu bu tezin pratik olarak ne kadar doğru olduğunu göstermektedir. Yazar şikâyet ettiği parçalı yapıyı besleyen tutumuyla kendi iddiasını örneklemektedir.

Bütün bunlara rağmen gerek roman içerisinde gerekse romanın finalinde gerçekleşen bağımsız devletin kuruluşu ile yazar, ümitsiz olmadığını da hissettirir. Kapez, gelecekten ümitsiz olan Kitapbek'e şunları söyler:

"Bu savaştan vazgeçmek yoktur. Çünkü bu savaş millet olmanın, birlik olmanın savaşıdır. $\mathrm{Bu}$ yüzden senle biz bu savaşta kazanacağız, biz kazanamasak da neslimiz kazanacak diye ümitle savaşmalıyız. Başka türlü düşünmek ihanet olur, halkın geleceği için endişelenmek dediğin budur." (Nurjekeulı, 2018; 253)

\section{Rus (Öteki) İmajı}

Eserde yer yer 'kendi' ve 'öteki' imaj1, insan olan ve olmayan genellemesine indirgense de bu tutum daha çok romancının yansız davranma, gerçekçi olma ve 'kendi' olarak biçimlenen Kazak kimliği içerisinde ötekileşen unsurları dışarıda bırakma; 'öteki' olarak düşünülen Rus ve Kalmuklar içerisinde 'kendi' imajına yakınlaşan unsurları ise içeri alma çabasından kaynaklanan geçici bir tutumdur.

Beksultan Nurjekeulı Rus imajını oluştururken acele etmez. Kahramanlarının bir ön yarg1 ile hareket etmelerine de izin vermez. Okuyucunun Ruslar konusundaki imajı olaylardan hareketle ve süreç içerisinde ikna olarak kavramasını ister. Romanın başındaki 'Sophia' ve daha sonra onun yerine yine Rusların zulmüne uğrayan bir Rus olan 'Kobzev'i koyarak eserin romantik bir noktaya kaymasını ve mesnetsiz, duygusal tezler içeren bir duruma düşmesini önlemeye çalışır. Kazak kimliğine dönük eleştirileri de yine eserin gerçekçi olma iddiasını desteklemek için kullanır.

Eserin ana kahramanı Şeyi romanın başında Rus imajı konusunda bilinçsizdir. Ruslara karşı bir ön yargı taşımaz. Esasında burada bir 'kendi' bilincinden de söz edilemez. 
Tazabek'in isminin anlamını ve şeceresini konuştukları ve atası 'Tazabek Pusırmanoğlu'ndan bahsettikleri bölümde Şeyi, bu tarihi şahsiyetin Ruslara neden karşı çıktığına da bir anlam veremez:

"Ruslara baş eğmek istemeyen Tazabek atalarının bu tavrına bir türlü anlam veremedi. Ruslar Kazaklar için iyi düşünüyorsa Kazakların Ruslara karşı ne tavrı var ki? Eğer Rusların niyeti iyiyse Çin'e geçtiği için Tazabek'i neden tutuklamıştı? Bunların hepsi Şeyi'nin bilmek isteyip de anlayamadığı kafasındaki sorulardı." (Nurjekeulı, 2018; 22)

Şeyi bu soruların etkisi ile olacak Tazabek'in de bir Rus'un yanında çalışıyor olmasındaki tenakuza işaret ederek onun da bilinç düzeyinin okuyucu tarafindan görülmesini sağlar: "Tazabek atan halkını düşünüp Ruslara karşı çıkmış, sen ise kendi rahatın için Ruslara hizmet ediyorsun!” (Nurjekeul1, 2018; 21)

Bütün roman bu iki kahraman üzerinden Kazak kimliğini süreç içerisinde oluştururken bir yandan da Rus imajını somut olay ve deliller üzerinden inşa eder. Romanın sonuna geldiğinde okuyucu Şeyi'nin hâlâ olayın farkında olmadığını görür. Torunu Nurbek'in 1985 Aralık'ında yapılan genel kurulda alınan karar gereği Kazakistan'ın bir Rus'un yönetmesine itirazını anlamaz: "Eee, (hep) Rus olmuyor muydu, birçok Rus yönetmişti Kazakistan'ı." (Nurjekeul1, 2018; 306) Şeyi Almatı'daki gençlerin bu karar sebebiyle hükümete karşı çıkmasına da bir anlam veremez. Çünkü onlar Rusları tanıyacak kadar tecrübeye sahip değildir. Tecrübesi olmayan bu tavrı gerçekçi bulmaz:

'Sonunda duydu ki Almatı'daki gençler hükümete karşı çıkmışlar. Hükümete! İnsan aklına gelmeyecek şey. Yakınlarından ayrılan, göreceğini gören Kazaklar ile eziyet çekenler olsa iyiydi ama gençler niye ayaklanıyordu? Ne işi vardı onların, onlar ne bilirdi ki?" (Nurjekeul1, 2018; 306)

Kazakistan'da insanların eğitim sayesinde geldiği bilinç düzeyi Şeyi ile Nurbek ve Kavsar arasındaki düşünce farkıyla verilmek istenir. Rus, eski Rus’tur; fakat Kazak, eski Kazak değildir.

Kazak topraklarına gelen ilk Ruslar, sonradan gelen Ruslardan farklıdır. Bu ilk gruptaki Rusların iyi olmasının sebebi Kazakları yakından tanıma, onlarla iletişim kurma ve onlardan yardım alma gibi makul sebeplere dayanmaktadır. Yani bu durum, Rusların iyi ya da kötü olmasından çok Kazakların iyi olması ile ilgilidir. Kazaklara minnetle bağlı olan bu gruptaki Ruslardan Kobzev Kitapbek’in: “Sizin Ruslar güvenilir mi?” sorusuna şöyle cevap verir:

"Hepsi güvenilir, hepsi Kazaklardan yardım görmüş, ilk gelen Ruslardandır. Şimdi gelenler ise bize hiç benzemiyorlar, çünkü biz buraya geldiğimizde hiçbir Rus yoktu, bize sadece Kazaklar yardım etti, şimdi gelen Ruslar ise önceden gelen Ruslara katılıyor. İşleri düşmeyince Kazakların nasıl yardımsever bir halk olduklarını bizim kadar bilmezler." (Nurjekeul1, 2018; 240)

Eserde Kazaklara yakın davranan Rusların tavrı buradan anlaşılacağı üzere Kazakların iyiliğine karşı duydukları minnetin bir neticesidir. Tazabek'in evini kundaklayarak ailesini öldürmek isteyen Rus ile onları yanmaktan ve boğulmaktan son anda kurtaran ve bunun karşılığında kendisine verilen hediyeye bile tenezzül etmeyen Rus arasındaki fark, yukarıda verilen detay sebebiyle çok anlaşılmaz değildir (Nurjekeulı, 2018; 228).

Kazak topraklarına sonradan gelen Ruslar Kazakların tarihini, geleneklerini, âdetlerini bilmezler. Bir kısmı onların bu değerlere hiç sahip olmadığını düşündükleri için onlara saygı duymaz, hatta onları insan olarak bile görmezler (Nurjekeulı, 2018; 160). Segeyçük'ün kardeşlerinin hatalarını dikkate almayıp onları öldüren Kazakları suçlaması da aslında bu bakışın bir neticesidir (Nurjekeulı, 2018; 180). Kazak topraklarına ilk gelen Ruslar da daha 
sonra gelenler de Kazak coğrafyasına Kazaklara hizmet etmek için gelmez. Tam aksine kendi devletlerini büyütmek, zenginliklerini artırmak için gelir (Nurjekeulı, 2018; 160, 192). Kazaklara bakışları farklı olsa da her iki grubun bu topraklara geliş amacı aynıdır. Fakat Kazaklara bakışlarının farklı oluşu amaçlarına ulaşma yöntemlerini de farklılaştırır. İlk Ruslar uzlaşmacı, âdil, kadirşinas insanlarken daha sonra gelenlerde bu özelliklere rastlanmaz. Sonradan gelen gruplar yayılmacı ve işgalci bir hareket tarzı izler.

Devletlerinin gücünü de arkalarına alan ve nihaî amaçlarını gerçekleştirmek için çalışan Rusların en büyük özelliği çıkarcı, hilekâr ve siyasî bir tavırla saf Kazakları kandırmasıdır. Romanda işlenen sürecin hemen tüm safhalarında bu özellik bariz olarak görülür. Hem Çarlık döneminde askere alma bahanesiyle çıkarttıkları isyan sebebiyle Kazakları kendi topraklarından sürerken hem de Sovyet zamanında onların en verimli topraklarını, işleme bahanesiyle sahiplenirken bu taktiği izlerler (Nurjekeulı, 2018; 42, 193).

Ç1karc1, sömürgeci siyaset ile hile ve yalan konusunda Çar idaresi ile Sovyet idaresi arasında hiçbir fark yoktur. Çarlık dönemi Rusları Kazakların tarihini, geleneklerini bilmedikleri; hatta onların bir tarihinin hiç olmadığını düşündükleri için Kazaklara saygı duymaz, onları insan yerine dahi koymaz (Nurjekeulı, 2018; 160). Sovyet Rusya's1 ise Kazakların bir geleneklerinin ve tarihlerinin olduğunu öğrendiği halde 'yeni tarih' yapma iddiası ve türlü vaatlerle kandırdığı; güç, hile ve siyaset kullanarak zorla kurduğu Sovyet iktidarı ile halkın malını elinden alarak onları ölüme terk eder (Nurjekeulı, 2018; 310-311, 315). Çar tahttan gitmiş olsa da Rus yerli yerindedir (Nurjekeulı, 2018; 145).

Rusların hile ve siyaset için kullandıkları araçlar ise yasalar, orduları, eğitim ve işbirlikçilerdir (Nurjekeulı, 2018; 97). Yazılı bir yasası bulunmayan, bir araya gelip ordu kuramayan ve eğitimi umursamayan Kazak halkını yine kendi içlerindeki menfaat düşkünü ya da fesat kimseler eliyle alaşağı ederler. Bu sebeple Kazaklar için Ruslar zaman içerisinde güvenilmez bir imaj kazanır. Bu konuda önce Kazakları askerlik bahanesiyle öldüren, Çin’e süren Rus'un sonra yeniden topraklarına kabul etmesi üzerine Kojabek şunları söyler: "Yalnız dün bizi sürgün eden Rus'un fikrinin aniden değiştiğine başkast inansa da ben inanmam. Hâkimden gelen buyruğu olabilir." (Nurjekeul1, 2018; 141) Tazabek, can düşmanı Sergeyçük'le birlikte Sovyet idaresi kurulduğunda yönetici olarak atanan Sekerin'in yardımcısı olur. Bir toplantı esnasında Sekerin'in 1916 yılında sivil Rusların Çar tarafından Kazaklara karşı gizlice silahlandırıldığını öğrenir (Nurjekeulı, 2018; 180). Bu durum Ruslara karşı güvensizliği daha da artırır.

Eserde Ruslarla ilgili en çok vurgulanan ikinci özellik adaletsizlikleridir. Âdil olmayan Rus bu sebeple zalimdir. Hakkı olmayan toprakları ele geçirmek için her türlü kötülüğe tevessül edebilecek bir karaktere sahiptir. Rusların adaletsiz olduğu eserde bizzat bir Rus'un ağzından verilir. Sophia Tazabek'in: "Sen kimin tarafindasın?" sorusuna şöyle cevap verir:

"Ben eskiden beri adaletsizliğe karşıyım! Onu Rus mu yapar, Kazak mı benim için fark etmez! Tabi ki kendi halkıma ateş etmeyeceğim; fakat elimden geldiğince Kazaklara yardımımı esirgemem! Çünkü ben onların toprağında yetiştim ve yaşıyorum!” (Nurjekeulı, 2018; 54)

Bu cevapla tartışma konusu toprakların kime ait olduğu ve adaletten ayrılanın kim olduğu da ortaya konur. Eserin başında gizlice silahlandırdığ 1 sivil halk eliyle hamile kadınları, çocukları, ihtiyarları sırf Kazak oldukları için katleden Rusların amacı soykırımdır. Rus milislerin başında soykırım yapan 'Fon-Berg' isimli Rus Sophia'nın Kazakların hiçbir şeyden haberi olmayan savunmasız çoluk çocuğunu neden öldürdüğünü sorunca Rusların Kazaklara bakışını ele veren şu ifadeleri kullanır: "Düşmanın çoluğu çocuğu, kadını olmaz; yoksa onlara acıyor musun?” (Nurjekeul1, 2018; 61) 
İsyancı olarak damgalanan silahsız, çaresiz ve suçsuz hamile kadınlar, küçük çocuklar acımasızca öldürülür. Dahası cenazelerine bile saygı gösterilmez ve cesetler deşilir, parçalanır, ağaçlara asılır (Nurjekeulı, 2018; 60-65). Bu duruma isyan eden 'Sophia' Rus olmaktan duyduğu utanç sebebiyle soyunu inkâr edip bir Kazak'la evlenir. Artık kendisine 'Kazak' denilmesini isteyen Sophia'nın bu tavrı sadece duygusal sebeplere dayanmaz. Postanede çalışan Sophia arka planda dönen tüm zalimane hesaplardan haberdardır (Nurjekeulı, 2018; 66). Tazabek de olan biten karşısında çok hiddetlenir. Yazarın Rus imajını okuyucunun bilinç seviyesine yerleştirmeye başladığı bu bölümlerde Tazabek'in soruları üzerinden onların ne kadar adaletsiz ve zalim oldukları işlenir:

"Rusların o kadar kinlenmesinde bu zavallıların ne suçu vardı? Erkekleri karşılık verdi diye öldürebilirler; fakat kızları, kadınları, anaları, çocukları kılıçla öldüren asker nasıl asker olabilir ki? Ona insan demek bile içinden gelmiyordu. Katiller! sadece katil değil vahşi katiller! (...) Maksatlarının dünyadaki Kazakların hepsini yok etmek olduğu bellidir. Yoksa asker, karşısına çıkan askerle savaşmaz mıydı? Savunmasız halkla, çoluk çocukla, karıyla, kocayla ne işi vardı?" (Nurjekeulı, 2018; 65)

Yazar eserde özellikle katliam sahnelerini yürek parçalayacak detaylarla verir. Bu detaylar sayesinde okuyucunun hem aklına hem kalbine hitap etmeye çalışır. Kahramanlarına bu sahnelerle ilgili kesin hüküm verdirmek yerine sorular sordurur. Bu soruların cevabını da Rus imajı için her anlamda hazırladığı okuyucuya havale eder:

"Karakola giden ana yoldan kırk elli adım uzakta cesedi şişmiş ölü bir kadın ve biri delikanlı diğeri daha çocuk iki erkeğin cesedi iki tarafta yatıyordu. Üçünden daha uzakta on iki ya da on üç yaşında bir oğlanın başını kılıçla kesmişlerdi. Bu çocuk da o kadının oğlu mu oğlu değil mi belirsizdi. Bir ailenin soyu bunlarla bitti mi, kim bilir? Tüm Kazaklar karşı çıkmış olsa da bu dördü Çar'ın buyruğuna karşı çıkmamış olabilir miydi? Hatta Beyaz Çar'ın Kara Çar'ın kim olduğunu biliyorlar mıydı bunlar acaba? (...) Gerçekten biz mi insan değiliz yoksa Ruslar mı insan değil?" (Nurjekeulı, 2018; 95)

1916 yılında yaşananların tüm suçu Çarlık idaresine aittir. 1932 ve 1948 yılında yaşanan kıtlığın suçlusu ise Sovyet idaresidir. Çar döneminde Kazakların bir kısmını öldürüp bir kısmını da sürgüne göndererek hayvanlarını ve topraklarını işgal eden Ruslar (Nurjekeul1, 2018; 145), Sovyet döneminde Kazakların alın teriyle kazandıkları mallara zorla el koyar ve zengin halk fakir düsser (Nurjekeul1, 2018; 280). 'Kolhoz' adı verdikleri halk birlikleri kurduklarını söyleyerek tüm mal ve gelirleri de ellerinden aldıkları Kazakları adeta göz göre göre açlığa ve ölüme mahkûm ederler (Nurjekeul, 2018; 277, 311). Özellikle 1932 yllındaki yönetici 'Goloşekin' halkın malının tamamını toplayınca halk muhtaç duruma düşer ve açlıktan ölür. Hayatta kalanlarsa fare deliklerindeki tohumları ve fareleri yiyerek hayata tutunabilenlerdir (Nurjekeul1, 2018; 314-315).

Sovyet döneminde bir ara Ruslara güvenmeye başlayan Kazaklar onların eğitim, özgürlük ve daha iyi bir gelecek vaadinin hepsinin aldatmacadan ibaret olduğunu anlar. Çarlık döneminde hile ile Kazakların topraklarını işgal eden Rusların Sovyet döneminde bu işgali kalıcı ve meşru hale getirmeye çalıştığını anlarlar. Her firsatta Kazakları aşağılayan Rusların derdi, vadettikleri gibi onların daha iyi bir eğitim alarak kendi ülkelerini yönetecek güce ulaşması değildir. Sergeyçük ile Tazabek'in Kazakların eğitim almaları konusundaki tartışması bu konuyu işler: "O da ne demek? Kazak çocuklarl okuyacak mı? Benim çocuklarıma patron mu olacak? (...) Şunu bil ki Tazabek, Kazak kırk sene eğitim alsa bile Ruslara bir şey öğretemez. (...) Kazaklar koyun bakmaktan başka bir şey öğrenemez." (Nurjekeul1, 2018; 216) 
Kazakların eğitim alarak kendilerini geliştirme çabaları da yine Ruslar tarafından engellenir. Rusça eğitim alan ve bildiklerini Kazak çocuklara öğreten Abıyır Türkebayev adlı biri ile Ruslara köle olarak çalışırken Rusça öğrenen Bekmirza Ruslar tarafından öldürülür (Nurjekeulı, 2018; 146). 'İki ayaklı hayvan avı' olarak adlandırdıkları bu cinayetleri işleyen Rusların, Kazakları insan olarak görmedikleri ve onlara hayat hakkı tanımadıkları açıktır.

Eğitimli ve çalışkan Kazak'a tahammül edemeyen Rus imajı, özellikle Sergeyçük ve Stalin'de somut örneğini bulur. Stalin'in doğum günü olan 22 Aralık tarihinin aynı zamanda en uzun gecenin olduğu gün olmasına da vurgu yapan yazar, onun doğum gününün bir dönem bayram olarak kutlanmasındaki ironiye de işaret eder. Onun idareci olarak bulunduğu dönemi Sovyet'in en uzun gecesi olarak düşündüren bu yaklaşımın sebebi Stalin'in zalimliğidir (Nurjekeulı, 2018; 307). Stalin, Kazakların önceki hayatı ile şimdiki hayatı arasındaki farkı anlayan ve halkına anlatmaya çalışanları; kolhoz yalanı ile halkın malına el koymasına, sonra onu sovhoz yaparak devletleştirmesine, Kazakistan'ın kendi kaderini kendisi çizen özgür bir devlet olacağını vadeden bir yasa çıkmasına rağmen buna izin verilmemesine karşı çıkanları 'halk düşmanı' ilan edip öldürür (Nurjekeulı, 2018;310-311).

Sovyet dönemi eserde 70 yıllık bir yalan iktidarı olarak anılır. Fakat 1985 'te Stalin'in, Hruşev'in zorbalık ve zulümle susturduğu insanlar, 70 yıl içerisinde her türlü engellemeye rağmen kendilerini eğitim ve bilimle geliştirip akıllarını kullanmaya ve siyasete katılmaya başlarlar. Nihayet Kazak kimliği yetkin bir noktaya ulaşır ve Şeyi’yi bile hayrete düşüren 1985 Aralık olayları yaşanır. Kayrat, Lazzat ve Erbol gibi gençlerin isimleri direnişin sembolü olur (Nurjekeulı, 2018; 311-312). Bu gençlerin karş1 çıktığ için aşağılanan Kazakların, 70 sene sonra iyi eğitim alarak yetişmiş insanları varken hâlâ kendi devletlerini idare etmelerinin engellenmesidir (Nurjekeulı, 2018; 306). Şeyi'nin torunu Kavsar da bu haklı talebi sebebiyle suçlanır, sorgulanır ve istismara uğrar.

Bu olayları bastırmak için Sovyet Rusya'nın farklı yerlerden Almatı'ya asker getirmesi ile Çar hükümetinin 1916 yılındaki isyanı bastırmak için aynı yola başvurmuş olması arasında bir paralellik kuran yazar, esasında Rusların geçen zamana, güya değişen sisteme ve farklı idarecilere rağmen hiç değişmediğinin altını çizer (Nurjekeulı, 2018; 308).

Kitabın sonuna doğru Rus imajının netleştiği ve bu netleşmeye paralel olarak Rusların Kazaklar karşısında kaybettiği gözlenir. 1991 yılında Rusların gücün, hilenin ve siyasetin zoruyla kurduğu Sovyet iktidarı parçalanırken geçmişte ismi karalanan tüm Kazak aydınları ve Aralık olayında esrarkeş, alkolik ve kabadayı olarak suçlanan gençlerin de itibarı iade edilir (Nurjekeulı, 2018; 309, 315). Şeyi bütün bir ömür sanki bu anı bekliyor gibi Kazakistan'ın bağımsız bir devlet haline geldiğini öğrenir öğrenmez huzur içerisinde son nefesini verir (Nurjekeul1, 2018; 318).

\section{Rus Dışındaki İmaj Unsurları}

Rus imajının Kazak Kimliğini içeren 'kendi' imajının karşısında konumlanan ve Ruslar dışında farklı milletleri de içerisine alacak bir 'öteki’ imajı olduğunu söylemek mümkündür. Bu bağlamda 1916 yılındaki isyan ve göç sırasında Kazak halkının eski düşmanı Kalmuklar ile Kazakların topraklarına sığındığı Çinliler de Ruslar kadar acımasız ve firsatçıdır (Nurjekeulı, 2018; 106,143). Ruslara, Çinlilere ya da Kalmuklara muhtaç olmaktansa ölmeyi yeğleyen Şeyi ve diğer Kazaklar bunlar tarafından aşağılanır (Nurjekeulı, 2018; 112). 1916' da ve İkinci Dünya Savaşında Ruslara karşı savaşan Almanlar da Kazaklara verdikleri zarar bakımından diğerleri ile birlikte değerlendirilebilir.

Romanda en şaşırtıcı detay Kırgızlarla ilgili olandır. Yazar tam bir sebep göstermemekle birlikte Kırgızların Istıkgöl Sarıbağışı'ndan olan Tabay’ın üzerinden 
Kırgızları da öteki olarak gösterir (Nurjekeulı, 2018; 124). Tazabek, Jüzük'ü şaka yollu kocası Tabay'ın yanında çalıştığı Rus'un atlarını çalıp Kırgızistan'a götürebileceği konusunda uyararak 'Kırgız' halkını zımnen hırsızlığa meyilli olmakla suçlar. Tabay da bu zımnî suçlamayı onaylar bir biçimde cevap verir:

"Gitsem orada Jüzük gibi kadın bulunmaz, bulunsa da Saman ile Aben gibi çocuk yoktur, hatta bulunsa da senin gibi kardeş bulunmaz (...) O yüzden bundan sonra kötü de olsa enişteni Kırgız, Kırgız diye incitip rahatsız etme. Kazak, Kazak diye öv!” (Nurjekeulı, 2018; 148).

Rus, Kalmuk, Çin ve Almanların bile yer yer insan olmak yönüyle anlaşılmaya, mazur görülmeye çalışıldığı eserde, Kırgızlara dönük bu değerlendirmenin açık ve anlaşılır bir nedeni yoktur.

\section{Sonuç}

Son dönem Kazak edebiyatının yetiştirdiği önemli hikâye ve roman yazarları arasında önemli bir yere sahip olan Beksultan Nurjekeulı Türkiye Türkçesine aktarılan ikinci eseri olan 'Ey, Dünya Ey!' adlı romanında ele alınan tarihi olaylar, olabildiğince gerçekçi bir biçimde anlatılmaktadır. Türk Dünyasının yakın tarihine 1şık tutacak detaylar içeren romanda sadece Kazak Türklerinin tarihini değil, onlar üzerinden genel olarak Türk dünyasının 20. yüzyılda yaşadıkları hakkında genel bir bilgi edinmek mümkündür. Merkez kahramanlardan birinin İstanbul'da eğitim alması, Kırgız Türklerinden bir kahramana romanda yer verilmesi gibi detaylar oldukça önemlidir.

Eserde yazar, Kazak kimliğini ele alırken oldukça realist bir tutum takınmakla birlikte onu en ideal örnekler üzerinden anlatmaya çalışmaktadır. Konu edindiği dönemi her şey olup bittikten sonra objektif bir biçimde anlatmanın zorluğuna rağmen olayları birçok açıdan değerlendirmeye çalışır. Kazak Türkleri özelinde Türk dünyasının geçen yüzyıldaki parçalı ve içler acısı hali gözler önüne serilir. Özelde Kazak Türkleri, genel anlamda Türk dünyası için birlik olma umudunun ve zaruretinin altı çizilir. Eğitimsiz ve siyasi vizyonu olmayan bir milletin düşebileceği sıkıntılı durumlar gerçek kahramanlar ve gerçek olaylar da kullanılarak aktarilır.

\section{KAYNAKÇA}

Açık, F. (2014). Dil ve Kimlik Bağlamında Türk Dünyası, (I. Uluslararası Türk Dünyası Araştırmaları Sempozyumu Bildiriler Kitabı Cilt 1) içinde (s.145-156). Niğde.

Altınmakas, L. (2014). Hanlık Devrinden Günümüze Örneklerle Kazak Edebiyatı (1. Baskı). İstanbul: Bilge Kültür Sanat Yayınları.

Dilek, İ - Ahmetova, A. (2017). XXI. Ғасырдағы Қазақ Романдарындағы "Мәңгілік Ел" Концептінің Ментальды Құрылымдары. Avrasya Sosyal ve Ekonomi Araştırmaları Dergisi, Cilt 4, Sayı 10, s.69-79.

Engin, E. (2012). İmagoloji. Selçuk Üniversitesi Edebiyat Fakültesi Dergisi, Sayı 27, s.57-66. Kaşgarlı, S. M. (2004). Uygur Türkleri Kültürü ve Türk Dünyası (1. Baskı). İstanbul: Çağrı Yayınları.

Kayımova, N. (2008, 1 Temmuz). Ақыьн Көдек Байшыванұльнна - 120 Жыл. https://turkystan.kz/article/56568-a-yn-k-dek-bajshy-an-lyna-120-zhyl, Erişim Tarihi: 18.02.2019.

Kınac1, C. (2011), Kazak Şairi Mağcan Cumabayoğlu'nun Şiirlerinde Kendi ve Öteki İmajı. Turkish Studies Cilt 6, Sayı 3, s.1663-1678.

Kınacı, C. (2016a), Kazak Edebiyatında Imaj ve Kimlik (1. Baskı). Ankara: Bengü Yayınları. 
Kınacı, C. (2016b), Bir Pişmanlık Bir Ümit. Gazi Türkiyat, Sayı 18, s.239-242.

Köseoğlu, N. (2013). Milli Kültür ve Kimlik. İstanbul: Ötüken Neşriyat (İlk baskı 1992).

Nurjekeul, B. (2017, 13 Kasım), “Жазушы Бексұлтан Нұржекеұлының бір күні” (Söy. Martha Alinova). https://adebiportal.kz/kz/news/view/19006, Erişim Tarihi: 15.02.2019.

Nurjekeulı, B. (2018). Ey, Dünya-Ey (1. Baskı) (Çev. G. Shaikenova). Ankara: Bengü Yayınları.

Özdemir, A. (2014). Kazak Edebiyatında Hikâye. İstanbul: Ötüken Neşriyat.

Smith, A. D. (1994). Millî Kimlik (1. Baskı) (Çev. B. S. Şener). İstanbul: İletişim Yayınları.

Talun İnce, A. (2008). Hans Dernschwam'ın İstanbul ve Anadolu'ya Seyahat Günlüğü’ndeki Türk İmajı Üzerine Bir İnceleme. Türkbilig, Sayı 15, s:110-125.

Tansu, Y. E. - Özdemir, R. (2017). Kenesarı İsyanı (1837-1847). Tarih ve Gelecek Dergisi, Cilt 3, Say1 3, s.208-220.

Topaloğlu, A. (2014). Güzel Türkçenin Sözlüğü (1. Bask1), İstanbul: Kap1 Yayınları.

Yalçın, A. (2012). Siyasal ve Sosyal Değişmeler Açısından Cumhuriyet Dönemi Türk Romanı 1920-1946. Ankara: Akçă̆ Yayınları (İlk baskı 2002).

Yıldız, S. (2007). Kimlik ve Ulusal Kimlik Kavramlarının Toplumsal Niteliği. Millî Folklor, Say1 74, s.9-16. 